\title{
ESTIMASI USIA DENGAN ORTHOPANTOMOGRAM PADA PASIEN RUMAH SAKIT GIGI DAN MULUT PENDIDIKAN UNIVERSITAS AIRLANGGA
}

\author{
Astika Swastirani*, Haryono Utomo**, Mieke Sylvia MAR** \\ * Departemen IPM, Fakultas Kedokteran Gigi Universitas Brawijaya, Malang \\ **Departemen Odontologi Forensik, Fakultas Kedokteran Gigi, Universitas Airlangga, Surabaya \\ Korespondensi: Astika Swastirani, E-mail: drgrani.pm@gmail.com.
}

\begin{abstract}
ABSTRAK
Gigi merupakan indikator yang kuat khususnya untuk estimasi usia karena keunikan dan kekuatannya. Estimasi usia kronologis dapat dilakukan dengan melihat tahap pertumbuhan dan perkembangan gigi dari orthopantomogram. Tujuan: menganalisis adanya perbedaan usia kronologis dan estimasi usia dengan orthopantomogram. Metode: sampel terdiri dari 100 rekam medis, 100 orthopantomogram digital milik 50 pasien laki-laki dan 50 pasien perempuan dari Rumah Sakit Gigi dan Mulut Pendidikan Universitas Airlangga. Orthopantomogram dicocokkan dengan atlas London. Hasil dari sampel laki-laki dan perempuan masing-masing dianalisis dengan uji pair $t$ - test. Hasil: hasil uji pair t-test pada sampel laki-laki ( $p$-value $0.002, p<0.05$ ) dan pada sampel perempuan ( $p$-value 0.605, $p>0.05$ ). Kesimpulan: terdapat perbedaan antara usia kronologis dan estimasi usia dengan orthopantomogram pada sampel laki-laki dan tidak ada perbedaan antara usia kronologis dan estimasi usia dengan orthopantomogram pada sampel perempuan di Rumah Sakit Gigi dan Mulut Pendidikan Universitas Airlangga.
\end{abstract}

Kata kunci : usia kronologis, estimasi usia, orthopantomogram 


\title{
AGE ESTIMATION USING ORTHOPANTOMOGRAM OF PATIENTS IN DENTISTY HOSPITAL OF AIRLANGGA UNIVERSITY
}

\begin{abstract}
Teeth are strong indicators for identification especially for age estimation because of their uniqueness and strength. Chronological age estimation can be done by looking at the stage of growth and development of teeth from orthopantomogram. objectives: To analyze the difference between chronological age and age estimation using orthopantomogram. Methods: Sample consisted of 100 medical records, 100 orthopantomograms digital belongs to 50 male and 50 female patients of Airlangga University Hospital of Dentistry. Orthopantomogram were matched with London atlas. The result from each sample in male and female was analyzed by pair $t$-test. Results: Result of the pair t-test in male ( $p$-value 0.002, $p<0.05$ ) and in female ( $p$ value 0.605, $p>0.05)$. Conclusions: There is difference between chronological age and age estimation using orthopantomogram in male and there is no difference between chronological age and age estimation using orthopantomogram in female in Airlangga University hospital of dentistry.
\end{abstract}

Keywords: chronological age, age estimation, orthopantomogram.

\section{PENDAHULUAN}

Usia kronologis adalah usia seseorang yang terhitung mulai dari tanggal lahir sampai sekarang atau saat dilakukan pemeriksaan. Tanggal lahir seseorang tercatat dalam akte kelahiran, rekam medis rumah sakit, database pemerintah, dan lain sebagainya. Saat tanggal lahir tidak tercatat di akte atau rekam medis maka perlu estimasi usia kronologis. ${ }^{1}$ Estimasi usia kronologis di kedokteran gigi digunakan untuk perawatan maloklusi orthodontik. ${ }^{2}$ Dalam kedokteran forensik estimasi usia kronologis untuk menentukan seseorang sudah atau belum cukup usia terlibat kasus hukum seperti perkosaan, penculikan, memperkerjakan anak di bawah umur, pernikahan, adopsi, imigrasi ilegal, dan pertanggung jawaban kasus kriminal oleh tersangka yang dicurigai belum cukup usia. Pada kasus kebakaran, kecelakaan, pembunuhan dan bencana massal, estimasi usia kronologis digunakan untuk identifikasi korban mati. ${ }^{3}$

Berbagai macam penelitian telah dilakukan untuk mengetahui estimasi usia kronologis dari gigi dan dimensi facial sehingga dapat digunakan untuk kasus 
forensik. ${ }^{4}$ Salah satu cara estimasi usia kronologis dapat dilakukan dengan melihat tahap pertumbuhan dan perkembangan gigi dari orthopantomogram dengan metode atlas London. Orthopantomogram biasa digunakan dalam pemeriksaan klinik seharihari dan menawarkan harga yang lebih murah karena paparan radiasi yang minimum. Orthopantomogram memberikan gambaran bilateral dan informasi yang cukup adekuat dalam pengukuran vertikal. Orthopantomogram dipertimbangkan sebagai standar pemeriksaan untuk diagnosis dan rencana perawatan oleh dokter gigi dan spesialis ortodontis. Beberapa penelitian menunjukkan orthopantomogram hasilnya dapat diterima, non-invasiv, biayanya terjangkau, dan paparan radiasi minimal. ${ }^{5}$

Atlas London menggunakan tahap pertumbuhan dan perkembangan gigi sebagai pedoman estimasi usia. Atlas London merupakan metode paling mudah dan komprehensif dalam menggambarkan tahap pertumbuhan dan perkembangan gigi. ${ }^{1,6}$

Beberapa hal diatas melatarbelakangi penulis untuk meneliti estimasi usia dengan orthopantomogram karena metode ini mudah, murah, sederhana, cepat didapat informasi dan non invasive sehingga dapat digunakan pada orang hidup dan mati. Penelitian mengenai estimasi usia kronologis menggunakan atlas London berdasarkan dan tahap pertumbuhan dan perkembangan gigi belum banyak di Indonesia.

\section{METODE}

Sampel yang digunakan berupa rekam medis dan orthopantomogram digital milik pasien usia 8-23 tahun selama periode 2010-2015 di Rumah Sakit Gigi dan Mulut Pendidikan Universitas Airlangga (RSGMPUnair). ${ }^{4}$ Keterangan kelaikan etik penelitian ini didapat dari Komisi Kelaikan Etik Penelitian Kesehatan (KKEPK) Fakultas Kedokteran Gigi Universitas Airlangga dengan nomor: 151/KKEPK.FKG/IX/2015. Penelitian dilakukan di Klinik Orthodonsia Rumah Sakit Gigi dan Mulut Pendidikan Universitas Airlangga (RSGMP-Unair).

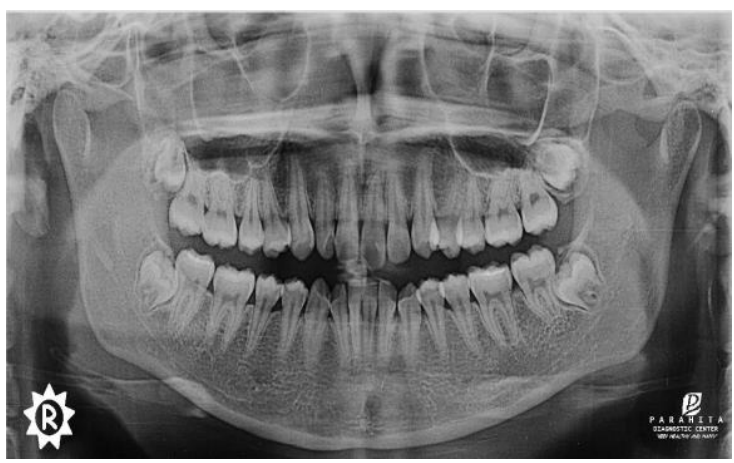

Gambar 1. Orthopantomogram milik pasien perempuan usia 17 tahun (koleksi pribadi).

Usia kronologis didapat dengan cara tanggal pembuatan orthopantomogram digital dikurangi tanggal lahir yang tertera di rekam medis pasien (usia kronologis= usia tanggal pembuatan orthopantomogram digital - tanggal lahir). Estimasi usia dengan orthopantomogram didapat dengan cara gigi molar ketiga rahang bawah di orthopantomogram dicocokkan dengan gambar tahap pertumbuhan dan perkembangan gigi pada atlas London. ${ }^{7}$ 


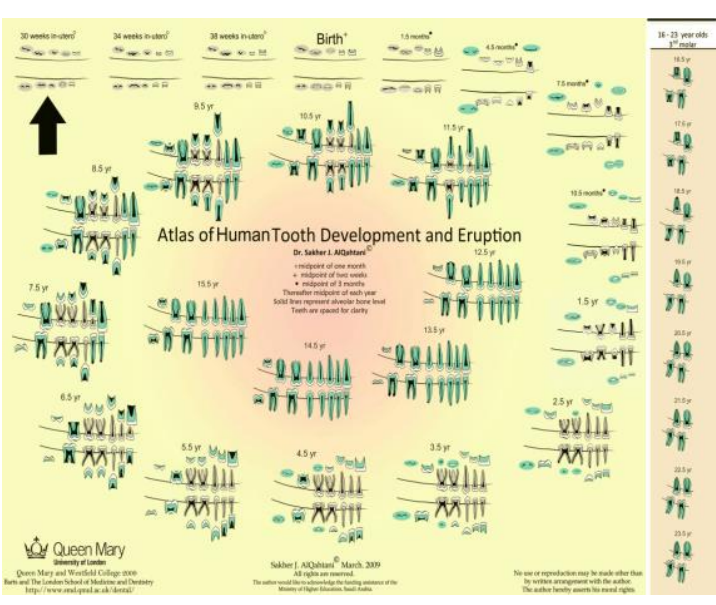

Gambar 2. Atlas London berdasarkan pertumbuhan dan perkembangan gigi. ${ }^{7}$

\section{HASIL}

Hasil uji pair t-test antara usia kronologis dengan estimasi usia dengan orthopantomogram pada sampel laki-laki dan perempuan disajikan dalam tabel 1 .

Tabel 1. Nilai $p$-value dari hasil uji pair $t$ -

test antara usia kronologis dengan estimasi usia dengan orthopantomogram

\begin{tabular}{|l|c|}
\hline Sampel & Nilai p-value \\
\hline Laki-laki & 0.002 \\
\hline Perempuan & 0.605 \\
\hline
\end{tabular}

\section{PEMBAHASAN}

Pada sampel laki-laki nilai dari $p-$ value 0.002 lebih kecil dari $a=0.05$ sehingga ada perbedaan antara usia kronologis dan estimasi usia dengan orthopantomogram. Hasil ini berlawanan dengan hasil uji pair t-test pada sampel perempuan. Nilai dari $p$-value 0.605 lebih besar dari $\mathrm{a}=0.05$ sehingga tidak ada perbedaan antara usia kronologis dan estimasi usia dengan orthopantomogram pada sampel perempuan.

Terdapat perbedaan antara usia kronologis dan estimasi usia dengan orthopantomogram pada sampel laki-laki dan tidak ada perbedaan antara usia kronologis dan estimasi usia dengan orthopantomogram pada sampel perempuan dalam penelitian ini sejalan dengan hasil penelitian yang dilakukan Alshihri dkk yang meneliti estimasi usia dengan atlas London pada populasi anak dan remaja di Saudi Arabia. ${ }^{8}$ Hasilnya ada perbedaan signifikan $(p<0.001)$ antara usia kronologis dan estimasi usia dengan orthopantomogram pada sampel penelitian. Akurasi estimasi usia berbeda pada sampel laki-laki dan perempuan. Untuk sampel usia 7-9 tahun estimasi usia pada sampel lakilaki dengan akurasi (80\%) dibanding sampel perempuan (63\%). Untuk sampel usia $\geq 16$ tahun, akurasi estimasi usia $57.1 \%$ pada laki-laki dan $47.6 \%$ pada perempuan. ${ }^{8}$

Hasil penelitian ini dengan hasil penelitian yang dilakukan oleh Al Qahtani dkk pada tahun 2014 yang meneliti akurasi metode atlas London dengan atlas Schour dan Massler dan atlas Ubelaker dengan mengambil sampel pada populasi orang London yang terdiri dari orang Bangladesh dan orang Inggris berkulit putih yang menyatakan atlas London akurat dalam memprediksi usia kronologis pada sampel laki-laki maupun perempuan dibanding atlas Schour dan Massler dan atlas Ubelaker. ${ }^{6}$ 
Penelitian ini tidak ada perbedaan antara usia kronologis dan estimasi usia dengan orthopantomogram pada sampel perempuan mungkin disebabkan karena perempuan mengalami growth spurt satu tahun lebih awal dibanding laki-laki sehingga pertumbuhan pada perempuan berhenti lebih awal dibanding laki-laki (1415 tahun vs 16-17 tahun). Temuan ini memberikan informasi bahwa pembentukan gigi mengikuti pola pertumbuhan umum yang dipengaruhi oleh perubahan hormon. Umumnya waktu erupsi gigi pada perempuan lebih cepat dibandingkan dengan laki-laki. Hal ini disebabkan karena adanya faktor hormon dimana estrogen berperan dalam pertumbuhan dan perkembangan sewaktu perempuan mencapai pubertas. Kenaikan hormon estrogen mempengaruhi proses kalsifikasi gigi lebih cepat pada perempuan. Kalsifikasi gigi yang lebih cepat menyebabkan gigi tumbuh sempurna sehingga gambaran gigi molar 3 pada orthopantomogram saat dicocokkan dengan atlas London hasilnya estimasi usia dengan orthopantomogram mendekati atau sama dengan usia kronologis. Sedangkan pada sampel lakilaki kalsifikasi gigi yang lebih lambat menyebabkan gigi lebih lambat tumbuh sempurna sehingga gambaran gigi molar 3 pada orthopantomogram saat dicocokkan dengan atlas London hasilnya estimasi usia dengan orthopantomogram berbeda dengan usia kronologis. Jumlah sampel yang heterogen pada tiap rentang usia pada kelompok sampel laki-laki dan perempuan mungkin menyebabkan variasi hasil pada saat analisis statistik. 8,9

Hal lain yang harus diperhatikan adalah variasi genetik, seks, etnis dan lingkungan mempengaruhi pertumbuhan dan perkembangan gigi. Gangguan pada pola pertumbuhan normal, seperti yang disebabkan oleh kekurangan gizi atau penyakit kronik menjadi sumber potensi kesalahan dalam estimasi usia. Perbedaan diantara sub-populasi lokal harus diperhatikan dan estimasi terbaik didapat dari standard spesifik populasi lokal. Waktu optimal untuk estimasi usia gigi sudah lama diketahui selama masa perkembangan gigi, yaitu di bawah pengaruh gen dan sedikit dipengaruhi faktor lokal. ${ }^{10}$

\section{KESIMPULAN}

Dengan keterbatasan dalam
penelitian ini maka disimpulkan ada
perbedaan antara usia kronologis dan
estimasi usia dengan orthopantomogram
pada sampel laki-laki dan tidak ada
perbedaan antara usia kronologis dan
estimasi usia dengan orthopantomogram
pada sampel perempuan sehingga metode
atlas London dapat digunakan untuk
estimasi usia pada sampel perempuan,
namun tidak bisa digunakan pada sampel
laki-laki di Rumah Sakit Gigi dan Mulut
Pendidikan Universitas Airlangga.

\section{UCAPAN TERIMA KASIH}

Ucapan terima kasih penulis sampaikan kepada Klinik Orthodonsia Rumah Sakit Gigi dan Mulut Pendidikan 
Universitas Airlangga dan semua pihak yang telah membantu penelitian ini.

\section{DAFTAR PUSTAKA}

1. Adams C, Carabott R, Evans S. Forensic Odontology: An Essential Guide. 1st edition. West Sussex: John Wiley and Sons Ltd; 2014; p.138-9.

2. Proffit WR, Field WH, Sarver MD. Contemporary Orthodontics. 4th ed. Missouri: Mosby Elsevier; 200; p. 33.

3. Bagh $T$, Chatra $L$, Shenai $P$, Veena KM, Rao KP, Prabhu VR, Kushraj T, Shetthy P. Age Estimation using Cameriere's Seven Teeth Method with Indian Specific Formula in South Indian Children. Intern J Advanced Health Science. 2014; 1(2): 2-10.

4. Rai B, Krishan K, Kaur J, Anand CS. Age Estimation from Mandible by Lateral Cephalogram: Preliminary Study. J For Odont. 2008; 27(1): 2428.

5. Gupta, S, Jain, S. Orthopantomographic Analysis for Assessment of Mandibular Asymmetry. J of Indian Orthodontic Society. 2012; 46(1): 33-7.

6. Al qahtani SJ, Hector PM, Liversidge MH. Accuracy of Dental Age Estimation Charts: Schour and Massler, Ubelaker, and The London Atlas. Am J Physical Anthrop. 2014; 154(1): 70-8.

7. Al qahtani SJ, Hector PM, Liversidge $\mathrm{MH}$. Brief communication: the London atlas of human tooth development and eruption. Am J Physical Anthrop. 2010; 142(3): 481-90.

8. Alshihri MA, Kruger $E$, Tennant $M$. Dental Age Assessment of Western Saudi Children and Adolescent. Saudi Dent J. 2015; 27(3):131-6.

9. Koch G, Poulsen S. Pediatric dentistry: a clinical approach. 1st edition. West Sussex: Blackwell Publishing Ltd; 2009; p. 7-8.

10. Almonaitiene $\mathrm{R}$, Balciuniene I, Tutkuviene J. Factors Influencing Permanent Teeth Eruption. Stomatologija Baltic Dental and Maxillofacial Journal. 2010; 12(3): 6772. 